\title{
PENGARUH MINAT BELAJAR DAN SELF-REGULATED LEARNING TERHADAP HASIL BELAJAR MATEMATIKA PESERTA DIDIK
}

\section{THE INFLUENCE OF LEARNING INTEREST AND SELF- REGULATED LEARNING TOWARDS STUDENTS' MATHEMATICS LEARNING OUTCOMES}

\author{
Lisnasari Andi Mattoliang ${ }^{\mathrm{a}}$, Wanasari ${ }^{\mathrm{b}}$, Fitriani Nur ${ }^{\mathrm{c}}$, Muhammad Rusydi Rasyid ${ }^{\mathrm{d}}$, \\ Baharuddin $^{\mathrm{e}}$ \\ ${ }^{a}$ Program Studi Pendidikan Matematika FTK Universitas Islam Negeri Alauddin Makassar \\ Jl. H.M. Yasin Limpo Nomor 36 Samata-Gowa, lisnasari.mattoliang@uin-alauddin.ac.id \\ ${ }^{\mathrm{b}}$ Program Studi Pendidikan Matematika FTK Universitas Islam Negeri Alauddin Makassar \\ Jl. H.M. Yasin Limpo Nomor 36 Samata-Gowa, wanasari228@gmail.com \\ ${ }^{\mathrm{c}}$ Program Studi Pendidikan Matematika FTK Universitas Islam Negeri Alauddin Makassar \\ Jl. H.M. Yasin Limpo Nomor 36 Samata-Gowa, fitriani.nur@uin-alauddin.ac.id \\ ${ }^{d}$ Program Studi Pendidikan Matematika FTK Universitas Islam Negeri Alauddin Makassar \\ Jl. H.M. Yasin Limpo Nomor 36 Samata-Gowa, rusydi.rasyid@uin-alauddin.ac.id \\ ${ }^{\mathrm{e}}$ Program Studi Pendidikan Matematika FTK Universitas Islam Negeri Alauddin Makassar \\ Jl. H.M. Yasin Limpo Nomor 36 Samata-Gowa, baharuddin.abbas@uin-alauddin.ac.id
}

\begin{abstract}
ABSTRAK
Penelitian ini bertujuan untuk mengetahui pengaruh minat belajar dan self-regulated learning terhadap hasil belajar matematika peserta didik kelas VIII SMP Negeri 17 Makassar. Jenis penelitian ini adalah penelitian ex-post facto. Populasi dalam penelitian ini adalah seluruh peserta didik kelas VIII SMP Negeri 17 Makassar dengan jumlah 280 peserta didik, sedangkan sampelnya sebanyak 98 peserta didik yang dipilih dengan teknik simple random sampling. Instrumen yang digunakan adalah kuesioner minat belajar, kuesioner self-regulated learning, dan dokumentasi hasil belajar matematika. Data dianalisis menggunakan analisis regresi linear berganda. Hasil analisis menunjukkan bahwa minat belajar dan self-regulated learning secara bersama-sama berpengaruh secara positif dan signifikan terhadap hasil belajar matematika peserta didik kelas VIII SMP Negeri 17 Makassar.
\end{abstract}

Kata Kunci : minat belajar, self-regulated learning, hasil belajar matematika

\begin{abstract}
This study aimed to determine the influence of learning interest and self-regulated learning on the mathematics learning outcomes of the eighth-grade students of SMP Negeri 17 Makassar. It was ex-post facto research. The population in this study were all eighth-grade students of SMP Negeri 17 Makassar with 280 students, while the sample were 98 students chosen by using a simple random sampling technique. The instruments were learning interest questionnaire, self-regulated learning questionnaire, and documentation of mathematics learning outcomes. The data were analyzed with multiple linear regression analysis. The results indicated that learning interest and self-regulated learning jointly had positive and significant influences on students' mathematics learning outcomes of SMP Negeri 17 Makassar.
\end{abstract}

Keywords : learning interest, self-regulated learning, mathematics learning outcomes 


\section{Pendahuluan}

Matematika berperan penting dalam kehidupan karena terkait dengan bidang ilmu lainnya seperti ilmu pengetahuan alam, sosial, kedokteran, ekonomi dan sebagainya (Silviani et al., 2017). Dalam pembelajaran matematika, peserta didik dibekali kemampuan berpikir logis, analitis, sistematis, kritis, kreatif, dan bekerja sama (Ahmad, 2016).

Salah satu standar keberhasilan seseorang dalam dunia akademik adalah hasil belajar.

Menurut Zainal (2013), hasil belajar merupakan gambaran tentang apa yang harus digali, dipahami, dan dikerjakan peserta didik. Hasil belajar merefleksikan keluasan, kedalaman, kerumitan, dan suatu teknik penilaian dapat mengukur hasil belajar. Hasil belajar menggambarkan penguasaan dan keterampilan dalam kurun waktu tertentu (Ahmad, 2016). Berbagai faktor dapat memengaruhi tinggi rendahnya hasil belajar peserta didik. Faktor-faktor tersebut dapat menjadi fokus bagi pendidik dalam meningkatkan hasil belajar peserta didik. Secara umum, terdapat dua faktor yang berpengaruh terhadap hasil belajar, yaitu faktor internal dan faktor eksternal (Fasikhah \& Fatimah, 2013). Salah satu faktor internal yang dapat memengaruhi hasil belajar siswa adalah minat.
Minat adalah ketertarikan pada suatu hal atau aktivitas yang muncul dari dalam diri tanpa perintah orang lain (Slameto, 2010). Minat merupakan aspek afektif yang menunjang keberhasilan belajar. Hal ini disebabkan karena aktivitas yang dilakukan didorong oleh suatu kekuatan dari dalam diri. (Vahlia et al., 2017). Syah (2010) juga mengungkapkan bahwa minat adalah kecenderungan yang tinggi atau keinginan yang besar terhadap sesuatu. Minat belajar merupakan suatu kecenderungan perasaan senang, tertarik serta memiliki perhatian lebih, keinginan yang besar terhadap sesuatu dalam kegiatan belajar. Minat sebagai salah satu faktor internal yang mempunyai peranan dalam menunjang hasil belajar siswa (Pangestu et al., 2015). Selain minat belajar, faktor yang perlu diperhatikan dalam pembelajaran adalah self-regulated learning. Pada tahun 1980an, istilah self-regulated learning muncul dan berasal dari peningkatan fokus pada pengaturan diri dalam lingkungan akademik. (Dinsmore et al., 2008). Liu (2016) menyatakan selfregulation bertujuan untuk menyelesaikan masalah dengan efektif. Self-regulated merupakan perilaku yang muncul dari diri sendiri tanpa arahan dari orang lain (Alkusaeri, 2013). Menurut Schraw et al. (2006), self-regulated learning terkait dengan kemampuan memahami dan 
mengontrol lingkungan belajar. Selfregulated learning merupakan kesiapan dari individu yang mau dan mampu untuk belajar dengan inisiatif sendiri, dengan atau tanpa bantuan pihak lain dalam proses dan evaluasi pembelajaran (Sugiyana, 2015). Self-regulated learning merupakan kegiatan dimana individu yang belajar secara aktif sebagai pengatur proses belajarnya sendiri, mulai dari merencanakan, memantau, mengontrol dan mengevaluasi dirinya secara sistematis untuk mencapai tujuan dalam belajar, dengan menggunakan berbagai strategi baik kognitif, motivasional maupun behavioral (Fasikhah \& Fatimah, 2013; Panadero, 2017). Dengan memiliki self-regulated learning yang baik, peserta didik akan mendapatkan prestasi akademik yang baik (Fasikhah \& Fatimah, 2013). Listyani dalam Saefullah et al. (2013) menjelaskan bahwa terdapat enam indikator self-regulated learning, yaitu tidak bergantung kepada orang lain, percaya diri, disiplin, bertanggung jawab, berinisiatif, dan mampu mengontrol diri.

Beberapa penelitian terkait minat belajar maupun self-regulated learning telah dilakukan. Hasil penelitian Sirait (2016) menunjukkan bahwa terdapat hubungan yang signifikan antara minat belajar dan hasil belajar matematika. Latipah (2015) menyimpulkan bahwa selfregulated learning berperan positif dalam meningkatkan hasil belajar peserta didik. Chen dan Huang dalam Yamada et al. (2017) juga menyatakan bahwa selfregulated learning meningkatkan hasil pembelajaran. Minat belajar dan selfregulated learning merupakan aspek penting dari pembelajaran. Hal itulah yang mendasari dilakukannya penelitian yang bertujuan untuk mengetahui pengaruh minat dan self-regulated learning secara simultan terhadap hasil belajar peserta didik kelas VIII SMP Negeri 17 Makassar.

\section{Metode Penelitian}

Jenis penelitian ini adalah penelitian ex-post facto. Pada penelitian ini tidak diberikan perlakuan terhadap variabel yang diteliti. Populasi dalam penelitian ini adalah seluruh peserta didik kelas VIII SMP Negeri 17 Makassar yang terdiri dari 8 kelas dengan jumlah 280 peserta didik. Sampel penelitian adalah $35 \%$ dari seluruh peserta didik kelas VIII SMP Negeri 17 Makassar yaitu 98 peserta didik dengan menggunakan teknik simple random sampling. Instrumen yang digunakan adalah kuesioner minat belajar, kuesioner self-regulated learning, dan dokumentasi hasil belajar matematika. Teknik analisis yang digunakan adalah analisis statistik deskriptif dan analisis statistik inferensial. Data minat belajar, self-regulated learning, dan hasil belajar 
dikelompokkan dengan menggunakan pengkategorian pada Tabel 1 .

Tabel 1. Kriteria Penskoran

\begin{tabular}{cl}
\hline Batas Kategori & Keterangan \\
\hline$X<(\mu-1,0 \sigma)$ & Rendah \\
$(\mu-1,0 \sigma) \leq X<(\mu+1,0 \sigma)$ & Sedang \\
$(\mu+1,0 \sigma) \leq X$ & Tinggi \\
\hline \multicolumn{2}{c}{ Sumber: (Azwar, 2004) }
\end{tabular}

Analisis inferensial menggunakan uji regresi linear berganda. Sebelum itu, peneliti melakukan uji prasyarat yang meliputi uji normalitas, uji linieritas, uji multikolinearitas dan uji heteroskedastisitas.

\section{Hasil dan Pembahasan}

Berikut adalah tabel hasil analisis deskriptif data minat belajar peserta didik kelas VIII SMP Negeri 17 Makassar.

Tabel 2. Minat Belajar Peserta Didik Kelas VIII SMP Negeri 17 Makassar

\begin{tabular}{ll}
\hline Statistik & Skor Statistik \\
\hline Sampel & 98 \\
Skor terendah & 35 \\
Skor tertinggi & 58 \\
Rata-rata & 45,19 \\
Standar deviasi & 6,411 \\
\hline
\end{tabular}

Jika nilai minat belajar peserta didik dikategorikan menjadi 3 kategori yaitu rendah, sedang dan tinggi, maka diperoleh data sebagai berikut.
Tabel 3. Kategori Minat Belajar Peserta Didik Kelas VIII SMP Negeri 17 Makassar

\begin{tabular}{cccc}
\hline Interval & Frekuensi & Persentase & Keterangan \\
\hline$X<39$ & 20 & $20,41 \%$ & Rendah \\
$39 \leq X<52$ & 59 & $60,20 \%$ & Sedang \\
$52 \leq X$ & 19 & $19,39 \%$ & Tinggi \\
\hline \multicolumn{4}{c}{$100 \%$} \\
\hline
\end{tabular}

Berdasarkan Tabel 3, dapat disimpulkan bahwa pada umumnya minat belajar peserta didik kelas VIII SMP Negeri 17 Makassar berada pada kategori sedang dengan persentase $60,20 \%$ dengan jumlah peserta didik yaitu 59 orang.

Berikut ini adalah tabel hasil analisis deskriptif data self-regulated learning peserta didik kelas VIII SMP Negeri 17 Makassar.

Tabel 4. Self-Regulated Learning Peserta Didik Kelas VIII SMP Negeri 17

\begin{tabular}{ll}
\multicolumn{2}{c}{ Makassar } \\
\hline Statistik & Skor Statistik \\
\hline Sampel & 98 \\
Skor terendah & 34 \\
Skor tertinggi & 58 \\
Rata-rata & 44,19
\end{tabular}

Standar deviasi $\quad 6,474$

Jika nilai self-regulated learning peserta didik dikategorikan menjadi 3 kategori yaitu rendah, sedang, dan tinggi, maka diperoleh data pada Tabel 5.

Tabel 5. Kategori self-regulated learning Peserta Didik Kelas VIII SMP Negeri 17 Makassar

\begin{tabular}{cccc}
\hline Interval & Frekuensi & Persentase & Keterangan \\
\hline$X<38$ & 16 & $16,33 \%$ & Rendah \\
$38 \leq X<51$ & 66 & $67,34 \%$ & Sedang \\
$51 \leq X$ & 16 & $16,33 \%$ & Tinggi \\
\hline & 98 & $100 \%$ & \\
\hline
\end{tabular}


Berdasarkan Tabel 5, dapat disimpulkan bahwa self-regulated learning peserta didik kelas VIII SMP Negeri 17 Makassar berada pada kategori sedang dengan persentase $67,34 \%$ dengan jumlah peserta didik yaitu 66 orang.

Berikut ini adalah tabel hasil analisis deskriptif data hasil belajar matematika peserta didik kelas VIII SMP Negeri 17 Makassar.

Tabel 6. Hasil Belajar Peserta Didik Kelas VIII SMP Negeri 17 Makassar

\begin{tabular}{ll}
\hline Statistik & Skor Statistik \\
\hline Sampel & 98 \\
Skor terendah & 60 \\
Skor tertinggi & 90 \\
Rata-rata & 75,69 \\
Standar deviasi & 7,535 \\
\hline
\end{tabular}

Jika nilai hasil belajar matematika peserta didik dikategorikan menjadi 3 kategori yaitu rendah, sedang, dan tinggi, maka diperoleh data pada Tabel 7.

Tabel 7. Kategori Hasil Belajar Matematika Peserta Didik Kelas VIII

\begin{tabular}{|c|c|c|c|}
\hline \multicolumn{4}{|c|}{ SMP Negeri 17 Makassar } \\
\hline Interval & Frekuensi & Persentase & Keterangan \\
\hline$x<68$ & 17 & $17,30 \%$ & Rendah \\
\hline $68 \leq X<83$ & 60 & $61,22 \%$ & Sedang \\
\hline $83 \leq X$ & 21 & $21,48 \%$ & Tinggi \\
\hline & 98 & $100 \%$ & \\
\hline
\end{tabular}

Berdasarkan tabel di atas, dapat disimpulkan bahwa hasil belajar matematika peserta didik kelas VIII SMP Negeri 17 Makassar berada pada kategori sedang dengan persentase $61,22 \%$ dengan jumlah peserta didik yaitu 60 orang.

\section{Pengujian Asumsi}

Uji normalitas bertujuan untuk mengetahui apakah nilai residual memiliki distribusi normal. Uji normalitas dengan uji Kolmogorov-Smirnov diperoleh sig = $0,200>0,05$ artinya data residual berdistribusi normal. Hal ini dapat pula dilihat dari gambar 1 bahwa sebaran data berada di sekitar garis diagonal dan mengikuti arah garis diagonal. Dengan demikian, disimpulkan bahwa model regresi memenuhi uji normalitas.

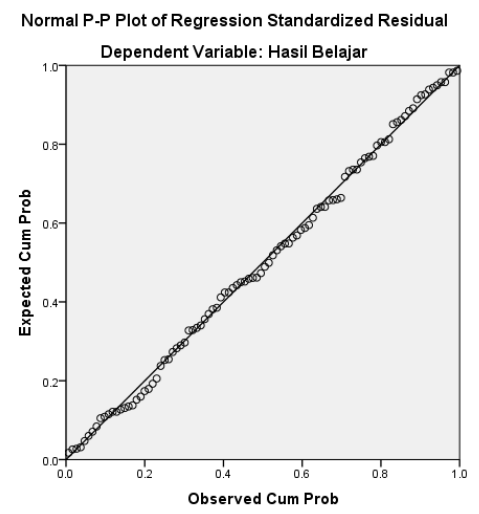

Gambar 1. Hasil Uji Normalitas Residual

Uji Linieritas dilakukan untuk mengetahui ada tidaknya hubungan linear antara variabel-variabel independen dan variabel dependen. Hasil pengujian linieritas dapat dilihat pada tabel 8.

\begin{tabular}{|ll}
\multicolumn{2}{c}{ Tabel 8. Hasil Uji Linieritas } \\
\hline & Sig \\
\hline Deviation from Linearity & 0,564 \\
\hline
\end{tabular}

Berdasarkan Tabel 8, hasil uji linieritas minat belajar dan self-regulated learning terhadap hasil belajar matematika diperoleh sig. Deviation from 
Linearity $=0,564>0,05$, berarti hubungan variabel minat belajar dan self-regulated learning terhadap hasil belajar matematika berupa hubungan linear sehingga disimpulkan bahwa asumsi linieritas dipenuhi.

Hasil uji multikolinearitas dapat dilihat pada Tabel 9.

Tabel 9. Hasil Uji Multikolinearitas

\begin{tabular}{lll}
\hline Variabel & Tolerance & VIF \\
\hline Minat belajar & 0,580 & 1,724 \\
$\begin{array}{c}\text { Self-regulated } \\
\text { learning }\end{array}$ & 0,580 & 1,724 \\
\hline
\end{tabular}

Berdasarkan Tabel 9, hasil uji multikolinearitas variabel minat belajar diperoleh nilai VIF sebesar 1,724 dan nilai tolerance sebesar 0,580 . Untuk variabel self-regulated learning diperoleh nilai VIF sebesar 1,724 dan nilai tolerance sebesar 0,580. Karena nilai VIF dari kedua variabel bebas kurang dari 10 dan nilai tolerance kedua variabel lebih dari 0,1 , maka dapat disimpulkan bahwa tidak terjadi multikolinearitas pada kedua variabel bebas tersebut. Berdasarkan syarat asumsi klasik regresi linear, regresi linear yang baik adalah yang terbebas dari adanya multikolinearitas.

Pengujian heteroskedastisitas dilakukan dengan uji Glejser dengan meregresikan nilai absolut residual terhadap variabel independen. Hasil uji heteroskedastisitas dapat dilihat pada Tabel 10.
Tabel 10. Hasil Uji Heteroskedastisitas

\begin{tabular}{ll}
\hline Variabel & Sig. (2-tailed) \\
\hline Minat belajar & 0,214 \\
\hline Self-regulated learning & 0,640 \\
\hline
\end{tabular}

Berdasarkan Tabel 10, hasil uji heteroskedastisitas variabel minat belajar diperoleh nilai signifikansi atau Sig. (2tailed) sebesar 0,214 dan nilai signifikansi variabel self-regulated learning sebesar 0,640. Karena nilai signifikansi kedua variabel independen lebih besar dari 0,05 maka dapat disimpulkan bahwa tidak terdapat gejala heteroskedastisitas. Artinya model regresi yang dipakai untuk penelitian ini layak untuk digunakan.

\section{Pengujian Hipotesis}

Analisis data untuk menguji pengaruh minat belajar dan self-regulated learning terhadap hasil belajar matematika peserta didik kelas VIII SMP Negeri 17 Makassar dilakukan dengan analisis regresi linear berganda. Hasil analisis menggunakan SPSS dapat dilihat pada Tabel 11.

Tabel 11. Hasil Uji ANOVA

\begin{tabular}{|c|c|c|c|c|c|}
\hline Model & $\begin{array}{l}\text { Sum } \\
\text { of } \\
\text { Squar } \\
\text { es }\end{array}$ & $\begin{array}{l}\mathrm{d} \\
\mathrm{f}\end{array}$ & $\begin{array}{l}\text { Mean } \\
\text { Squar } \\
\text { e }\end{array}$ & $\mathrm{F}$ & $\begin{array}{l}\text { Sig } \\
\text {. }\end{array}$ \\
\hline $\begin{array}{l}\text { Regressi } \\
\text { on }\end{array}$ & $\begin{array}{l}4515.3 \\
40\end{array}$ & 2 & $\begin{array}{l}2257.6 \\
70\end{array}$ & $\begin{array}{l}216.3 \\
23\end{array}$ & $\begin{array}{l}.00 \\
0^{\mathrm{b}}\end{array}$ \\
\hline Residual & $\begin{array}{l}991.47 \\
6\end{array}$ & $\begin{array}{l}9 \\
5\end{array}$ & 10.437 & & \\
\hline Total & $\begin{array}{l}5506.8 \\
16\end{array}$ & $\begin{array}{l}9 \\
7\end{array}$ & & & \\
\hline
\end{tabular}

Berdasarkan Tabel 11, nilai uji $\mathrm{F}$ sebesar 216,323 dengan signifikansi 0,000 $<0,05$ dan berdasarkan kriteria keputusan maka $H_{0}$ ditolak, artinya terdapat 
pengaruh minat belajar dan self-regulated learning secara bersama-sama dan signifikan terhadap hasil belajar matematika peserta didik kelas VIII SMP Negeri 17 Makassar.

Tabel 12. Model Summary

\begin{tabular}{llll}
\hline $\mathrm{R}$ & $\begin{array}{l}\mathrm{R} \\
\text { Square }\end{array}$ & $\begin{array}{l}\text { Adjusted } \\
\text { R Square }\end{array}$ & $\begin{array}{l}\text { Std. Error } \\
\text { of the } \\
\text { Estimate }\end{array}$ \\
\hline $.906^{\mathrm{a}}$ & .820 & .816 & 3.231 \\
\hline
\end{tabular}

Nilai $R$ square sebesar 0,820 , yang artinya besarnya persentase pengaruh minat belajar dan self-regulated learning secara bersama-sama terhadap hasil belajar matematika adalah $82 \%$.

\section{Pembahasan}

Penelitian ini membahas tentang pengaruh minat belajar, self-regulated learning terhadap hasil belajar matematika peserta didik kelas VIII SMP Negeri 17 Makassar. Jumlah sampel dalam penelitian ini adalah 98 dari 280 peserta didik kelas VIII SMP Negeri 17 Makassar. Responden diberikan angket minat belajar, angket self-regulated learning, dan dokumentasi hasil belajar peserta didik berupa nilai ujian semester.

Berdasarkan data hasil penelitian, hasil belajar diperoleh rentang skor 60 sampai 90, dengan nilai rata-rata sebesar 75,69 dan standar deviasi 7,535. Secara umum, nilai peserta didik berada pada kategori sedang sebesar $61,22 \%$. Namun, terdapat pula peserta didik yang memiliki nilai hasil belajar pada kategori tinggi sebesar $21,48 \%$. Beragamnya nilai hasil belajar peserta didik tentu disebabkan oleh berbagai faktor. Beberapa diantaranya yang menjadi perhatian dalam penelitian ini adalah minat dan self-regulated learning.

Berdasarkan data hasil penelitian, variabel minat belajar berada pada kategori tinggi sebesar 19,39\%, sedang sebesar 60,20\%, dan rendah sebesar $20,41 \%$. Mayoritas minat belajar peserta didik berada pada kategori sedang. Minat belajar merupakan salah satu faktor pendukung yang besar terhadap hasil belajar peserta didik. Minat belajar merupakan kondisi yang harus dimaksimalkan. Artinya, siswa harus dikondisikan agar mengalami kondisi yang nyaman. Siswa yang memiliki minat belajar yang baik akan dapat mengikuti pelajaran dengan baik pula sehingga akan mampu menghasilkan performa terbaik dalam belajarnya. Hasil yang diperoleh ini sesuai dengan hasil penelitian yang dilakukan oleh (Sirait, 2016) yang menunjukkan bahwa terdapat hubungan yang signifikan antara minat belajar dan hasil belajar matematika.

Berdasarkan data hasil penelitian, variabel self-regulated learning berada pada kategori tinggi sebesar 16,33\%, sedang sebesar $67,34 \%$, dan rendah sebesar 16,33\%. Mayoritas self-regulated learning peserta didik berada pada 
kategori sedang. Self-regulated learning merupakan salah satu faktor pendukung yang besar terhadap hasil belajar peserta didik. Enceng dalam (Sundayana et al., 2016) menyatakan bahwa semakin siswa mandiri, maka mengakibatkan hasil belajar siswa semakin meningkat. Hasil yang diperoleh ini sesuai dengan hasil penelitian yang dilakukan oleh (Liu, 2016) bahwa self-regulated learning memiliki dampak positif terhadap hasil belajar. Demikian pula hasil penelitian (Fasikhah \& Fatimah, 2013) bahwa self-regulated learning berpengaruh secara signifikan terhadap prestasi akademik.

Berdasarkan analisis deskriptif secara umum, skor variabel independen berada pada kategori sedang, demikian pula dengan variabel dependen. Berdasarkan analisis regresi linear berganda bahwa variabel minat belajar dan self-regulated learning secara bersama-sama berpengaruh positif terhadap hasil belajar matematika peserta didik. SMP Negeri 17 Makassar. Diperoleh pula bahwa pengaruh minat dan self-regulated learning terhadap hasil belajar peserta didik sebesar $82 \%$. Artinya, ada pengaruh dari faktor lain sebesar $18 \%$ terhadap hasil belajar peserta didik yang tidak diteliti dalam penelitian ini.

\section{Kesimpulan}

Berdasarkan hasil penelitian dan pembahasan, maka dapat ditarik kesimpulan bahwa minat belajar peserta didik kelas VIII SMPN 17 Makassar berada pada kategori sedang dengan skor rata-rata yang diperoleh yaitu 45,19 , selfregulated learning peserta didik dengan skor rata-rata 44,19 berada pada kategori sedang, dan hasil belajar matematika peserta didik kelas VIII SMPN 17 Makassar berada pada kategori sedang dengan nilai rata-rata yaitu 75,69 . Selain itu, diperoleh bahwa minat belajar dan selfregulated learning secara bersama-sama dan signifikan berpengaruh terhadap hasil belajar matematika yaitu sebesar $82 \%$.

\section{Pustaka}

Ahmad, S. R. S. (2016). Pengaruh Math Phobia, Self Efficacy, Adversity Quotient dan Motivasi Berprestasi terhadap Prestasi Belajar Matematika Siswa SMP. 3(2), 259-272.

Alkusaeri. (2013). Peningkatan Kemandirian dan Hasil Belajar Matematika Siswa dengan Metode STAD. Beta, 6(2), 108-124.

Azwar, S. (2004). Penyusunan Skala Psikologi. Pustaka Pelajar.

Dinsmore, D. L., Alexander, P. A., \& Loughlin, S. M. (2008). Focusing the conceptual lens on metacognition, self-regulation, and self-regulated learning. Educational Psychology Review, 20(4), 391-409. https://doi.org/10.1007/s10648008-9083-6 
Fasikhah, S. S., \& Fatimah, S. (2013). Self-Regulated Learning (SRL) dalam Meningkatkan Prestasi Akademik pada Mahasiswa. Jurnal Ilmiah Psikologi Terapan, 01(01), 145-155.

Latipah, E. (2015). Strategi Self Regulated Learning dan Prestasi Belajar: Kajian Meta Analisis. Strategi Self Regulated Learning Dan Prestasi Belajar: Kajian Meta Analisis, 37(1), 110-129. https://doi.org/10.22146/jpsi.7696

Liu, H. K. (2016). Correlation Research on the Application of E-Learning to Students, Self -Regulated Learning Ability, Motivational Beliefs , and Academic Performance. 12(1), 1091-1100. https://doi.org/10.12973/eurasia.2 $016.1559 \mathrm{a}$

Panadero, E. (2017). A Review of SelfRegulated Learning: Six Models and Four Directions for Research. Frontiers in Psychology, 8(APR), $1-28$.

https://doi.org/10.3389/fpsyg.201 7.00422

Pangestu, A. D., Samparadja, H., \& Tiya, K. (2015). Pengaruh Minat terhadap Hasil Belajar Matematika Siswa SMA Negeri 1 Uluiwoi Kabupaten Kolaka Timur. Jurnal Penelitian Pendidikan Matematika, 3(2), 17-26.

Saefullah, A., Siahaan, P., \& Sari, I. M. (2013). Hubungan antara Sikap Kemandirian Belajar dan Prestasi Belajar Siswa Kelas X pada Pembelajaran Fisika Berbasis Portofolio. Wahana Pendidikan Fisika (WaPFi), 1(1), 26-36. https://doi.org/10.17509/wapfi.v1i 1.4891

Schraw, G., Kauffman, D. F., \& Lehman, S. (2006). Self-Regulated Learning. Encyclopedia of Cognitive Science, March 2019. https://doi.org/10.1002/04700188 60.s00671
Silviani, T. R., Lusyana, E., \& Hadi, A. R. (2017). Upaya Meningkatkan Minat Belajar Matematika Menggunakan Inquiry Based Learning Setting Group Investigation. Kreano, Jurnal Matematika Kreatif-Inovatif, 8(2), 150-161.

https://doi.org/http://dx.doi.org/10 $.15294 /$ kreano.v8i2.8404

Sirait, E. D. (2016). Pengaruh Minat Belajar terhadap Prestasi Belajar Matematika. Jurnal Formatif, 6(1), 35-43.

Slameto. (2010). Belajar dan FaktorFaktor yang Mempengaruhinya. Rineka Cipta.

Sugiyana. (2015). Pengaruh SelfRegulated Learning, SelfEfficacy, dan Perhatian Orangtua terhadap Prestasi Belajar Matematika Siswa. PSIKOPEDAGOGIA, 4(1), 63-72. Sundayana, R., Belajar, K., \& Masalah, P. (2016). Kaitan antara Gaya Belajar, Kemandirian Belajar, dan Kemampuan Pemecahan Masalah Siswa SMP dalam Pelajaran Matematika. 75-84.

Syah, M. (2010). Psikologi Belajar. Rajawali Pers.

Vahlia, I., Rahmawati, Y., \& Anjar, T. (2017). Efektivitas Pendekatan Saintifik berbasis Group Investigation dan Discovery Learning ditinjau dari Minat Belajar Mahasiswa. AKSIOMA: Jurnal Program Studi Pendidikan Matematika, 6(1), 128-135.

Yamada, M., Shimada, A., Okubo, F., Oi, M., Kojima, K., \& Ogata, H. (2017). Learning Analytics of The Relationships among SelfRegulated Learning, Learning Behaviors, and Learning Performance. Research and Practice in Technology Enhanced Learning. https://doi.org/10.1186/s41039017-0053-9 
Zainal, A. (2013). Evaluasi Pembelajaran. Remaja

Rosdakarya. 